\title{
Phage display as a tool for identifying HIV-1 broadly neutralizing antibodies
}

\author{
A.N. Chikaev ${ }^{1}$, A.P. Rudometov², Yu.A. Merkulyeva², L.I. Karpenko² \\ ${ }^{1}$ Institute of Molecular and Cellular Biology of the Siberian Branch of the Russian Academy of Sciences, Novosibirsk, Russia \\ 2 State Research Center of Virology and Biotechnology “Vector", Rospotrebnadzor, Koltsovo, Novosibirsk region, Russia

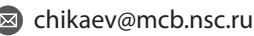

\begin{abstract}
Combinatorial biology methods offer a good solution for targeting interactions of specific molecules by a high-throughput screening and are widely used for drug development, diagnostics, identification of novel monoclonal antibodies, search for linear peptide mimetics of discontinuous epitopes for the development of immunogens or vaccine components. Among all currently available techniques, phage display remains one of the most popular approaches. Despite being a fairly old method, phage display is still widely used for studying protein-protein, peptide-protein and DNA-protein interactions due to its relative simplicity and versatility. Phage display allows highly representative libraries of peptides, proteins or their fragments to be created. Each phage particle in a library displays peptides or proteins fused to its coat protein and simultaneously carries the DNA sequence encoding the displayed peptide/protein in its genome. The biopanning procedure allows isolation of specific clones for almost any target, and due to the physical link between the genotype and the phenotype of recombinant phage particles it is possible to determine the structure of selected molecules. Phage display technology continues to play an important role in HIV research. A major obstacle to the development of an effective HIV vaccine is an extensive genetic and antigenic variability of the virus. According to recent data, in order to provide protection against HIV infection, the so-called broadly neutralizing antibodies that are cross-reactive against multiple viral strains of HIV must be induced, which makes the identification of such antibodies a key area of HIV vaccinology. In this review, we discuss the use of phage display as a tool for identification of HIV-specific antibodies with broad neutralizing activity. We provide an outline of phage display technology, briefly describe the design of antibody phage libraries and the affinity selection procedure, and discuss the biology of HIV-1-specific broadly neutralizing antibodies. Finally, we summarize the studies aimed at identification of broadly neutralizing antibodies using various types of phage libraries.

Key words: phage display; antibody libraries; HIV-1; broadly neutralizing antibodies (bnAbs).
\end{abstract}

For citation: Chikaev A.N., Rudometov A.P., Merkulyeva Yu.A., Karpenko L.I. Phage display as a tool for identifying HIV-1 broadly neutralizing antibodies. Vavilovskii Zhurnal Genetiki i Selektsii = Vavilov Journal of Genetics and Breeding. 2021;25(5):562-572. DOI 10.18699/VJ21.063

\section{Применение фагового дисплея для поиска ВИЧ-1-нейтрализующих антител}

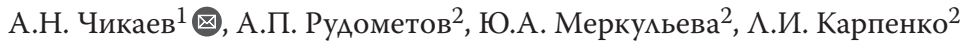 \\ ${ }^{1}$ Институт молекулярной и клеточной биологии Сибирского отделения Российской академии наук, Новосибирск, Россия \\ 2 Государственный научный центр вирусологии и биотехнологии «Вектор» Роспотребнадзора, р. п. Кольцово, Новосибирская область, Россия \\ 凶 chikaev@mcb.nsc.ru
}

\begin{abstract}
Аннотация. Комбинаторная белковая инженерия - востребованный инструмент для решения задач, связанных со скринингом большого разнообразия взаимодействующих молекул: разработки лекарств, средств диагностики, идентификации антител, поиска конформационных имитаторов антигенных детерминант для создания иммуногенов или компонентов вакцин. Среди всех подобных методик одна из наиболее популярных - технология фагового дисплея, появившаяся во второй половине 1980-х гг., однако в силу относительной простоты и универсальности по-прежнему активно применяющаяся для изучения белок-белковых, пептид-белковых и ДНК-белковых взаимодействий. Фаговый дисплей позволяет создавать высокопредставительные библиотеки пептидов, белков или их фрагментов, в которых каждая фаговая частица экспонирует на своей поверхности исследуемые пептиды или белки и одновременно несет в своем геноме последовательность ДНК, кодирующую экспонируемый пептид/белок. Процедура аффинной селекции позволяет находить специфические фаговые клоны практически к любой мишени, а за счет наличия физической связи между генотипом и фенотипом можно эффективно определить структуру отобранных молекул. Значительную роль технология фагового дисплея сыграла в исследованиях, направленных
\end{abstract}




\begin{abstract}
на изучение антигенной структуры вируса иммунодефицита человека (ВИЧ-1) и разработку средств борьбы с этим заболеванием. Серьезная проблема, из-за которой до сих пор не удается создать эффективную анти-ВИЧ-вакцину, - сильная антигенная изменчивость вируса. Согласно современным представлениям, для обеспечения защиты от инфицирования необходимо стимулировать индукцию в организме вируснейтрализующих антител, активных в отношении большого числа различных штаммов ВИЧ-1. Соответственно, идентификация подобных антител является важной исследовательской задачей. Тема настоящего обзора - применение фагового дисплея в качестве инструмента для поиска ВИЧ-1-нейтрализующих антител широкого спектра действия. Представлены ключевые характеристики технологии фагового дисплея, кратко описан процесс получения библиотек антител, проведения процедуры аффинной селекции, а также обсуждается феномен ВИЧ-1-нейтрализующих антител широкого спектра действия. Приводится обзор исследований, посвященных поиску кросс-нейтрализующих антител с использованием различных типов фаговых библиотек.

Ключевые слова: фаговый дисплей; библиотеки антител; ВИЧ-1; нейтрализующие антитела широкого спектра действия (bnAbs).
\end{abstract}

\section{Introduction}

Phage display was first described in 1985 by George Smith and Gregory Winter, who were awarded the 2018 Nobel Prize in Chemistry for this discovery. They reported that foreign peptides could be successfully expressed on the surface of bacteriophage particles by integrating a gene of interest into a phage genome upstream of its coat protein open reading frame (Smith, 1985). It is noteworthy that a conceptually similar study was independently conducted by a Russian scientific group led by A.A. Ilyichev, who incorporated a peptide-coding sequence into the pVIII protein gene of M13 phage (Ilyichev et al., 1992; Minenkova et al., 1993). Later, G. Smith and colleagues proposed a selection strategy for the enrichment of population of recombinant phage clones that specifically bind to the target ligand, using affinity enrichment process (Smith, 1985). Since there is a direct physical link between the genotype of the recombinant phage particle and the phenotype of the fusion protein, this method allows the identification of DNA sequences encoding selected molecules.

Subsequently, G. Smith and colleagues described the creation of combinatorial phage libraries that contain a large number of phage particles, each carrying a unique protein or peptide on its surface. Currently, one the most common types of phage libraries used for studying various proteinto-protein, receptor-ligand interactions or protein engineering are antibody phage libraries displaying single-stranded (scFv) and antigen-binding (Fab) fragments of IgG molecules (McCafferty et al., 1990; Winter et al., 1994). There are also alternative antibody formats used for the construction of antibody phage libraries, such as variable domains of antibodies from the heavy chains of camelids (VHH, or nanobodies) and sharks (vNAR) (Davies, Riechmann, 1995; Greenberg et al., 1995).

In order to create phage antibody library, antibody fragments to be exposed are usually fused to the N-terminus of the pIII phage coat protein. Despite the fact that all the phage coat proteins can be used for phage display, only pIII is suited to expose large peptides or proteins without loss of infectivity and functional activity of phage particles (Kay et al., 1993; Kishchenko et al., 1994; Mullen et al., 2006; Tikunova, Morozova, 2009). In early phage display systems, gene sequences encoding for antibody fragments were inserted directly into phage genome (McCafferty et al., 1990; Scott, Smith, 1990). Currently, a separate plasmid vector, also known as phagemid, is commonly used to introduce target DNA inserts into the phage genome. Phagemid carries recombinant pIII fusion gene, as well as phage and bacterial replication origins (thus can be replicated independently of phage production), but it lacks phage genes necessary for infecting, replicating, assembling and budding phage particles. In order to produce recombinant phages, phagemidtransformed Escherichia coli cells should be coinfected with a helper phage that carries wild-type phage genome including all the remaining phage genes required for the phage life cycle (Ledsgaard et al., 2018). The phage origin of replication in the phagemid enables its packaging into the forming virions as a single-strand DNA. Thus, the resulting phage particles contain both recombinant and wild-type forms of pIII from the helper-phage, so the infectivity is not compromised (Felici et al., 1991).

Immune libraries are usually generated from B-cell derived antibody repertoire of immunized animals or reconvalescent donors. Phage immune libraries contain about $10^{7}-10^{8}$ unique phage clones displaying antigen-specific antibodies on their surface (Kennedy et al., 2018). In some cases, "naive" libraries, based on lymphocyte mRNA of unvaccinated/ healthy donors, or intact animals, as well as "synthetic" libraries, based on de novo synthesized oligonucleotides, may be used in order to enhance diversity of the antibody repertoire (Griffiths, Duncan, 1998; Tikunova, Morozova, 2009). The representativeness of the phage libraries can reach up to $10^{9}-10^{10}$ for "naive" and $10^{10}-10^{11}$ for "synthetic" libraries (Zhao et al., 2016; Kennedy et al., 2018; Muyldermans, 2021).

\section{Construction of antibody phage display libraries}

The library's construction begins with RNA isolation from hybridoma cell lines, spleen cells from immunized animals, or B-lymphocytes from human peripheral blood, and subsequent cDNA synthesis (Clackson et al., 1991). Then, using isotype-specific primers, the variable regions of immunoglobulin light (VL) and heavy (HV) chain genes (or solely $\mathrm{VH}$ in the case of $\mathrm{VHH}$ ) are amplified and cloned 
into a phagemid vector between the pIII-encoding gene and $\mathrm{N}$-terminal signal sequence, which directs fusion protein to periplasmic translocation. These phagemids encoding diverse VH/VL gene combinations are then used for the transformation of E. coli cells that are co-infected with a helper phage, leading to the production of a set of phage particles exposing different antibody fragments (Skerra, Pluckthun, 1988; Tikunova, Morozova, 2009; Hammers, Stanley, 2014).

Following that, a biopanning procedure (a process of selecting phage clones that carry antigen-specific variants of antibody fragments) is carried out. To do this, the library is incubated with the target antigen that is immobilized on an immune plate, magnetic beads, or immunosorbent. Unbound particles are then washed, and a fraction of target-specific phages can be eluted using buffer with low or high $\mathrm{pH}$ or by adding a competing protein or peptide that strongly interferes with binding of the target molecule to selected phages (Smith, Petrenko, 1997). Another frequently used method of biopanning, probably the most effective, involves affinity selection using target molecules labeled with SS-biotin (Chames, Baty, 2010). The target molecule must be immobilized via a streptavidin-coated template. After that, the procedure involves standard incubation of the phage library and washing the unbound phage clones. SS-biotin contains a disulfide bond that can be cleaved by treatment with sulfhydryl, which enables the separation of a complex target (specific phage) from the substrate by adding a reducing agent such as dithiothreitol or 2-mercaptoethanol. This method provides a significant increase in the percentage of target-specific clones during biopanning, since the eluate obtained this way doesn't contain any phages that are nonspecifically bound to the substrate.

After each round of biopanning, eluted phage clones are used to infect E. coli, which are then cultured and superinfected with helper phage. The produced progeny phage particles are used for subsequent rounds of affinity selection. Commonly, one or two rounds of panning are enough to enrich the library with antigen-specific phage clones, though in the case of synthetic libraries (which are more representative but less specific) the number of rounds might be increased up to five.

Phage titering is done after every affinity screening to assess the amount of target-specific clones. The specificity of each phage clone can be assessed using enzyme-linked immunosorbent assay (ELISA), immunoblotting or flow cytometry. After the final round of biopanning, phages with the highest affinity are picked up, amplified, sequenced and used for phage DNA extraction and amplification of $\mathrm{VHH}$, Fab- or scFv-coding sequences, which are then subcloned into an expression vector in order to express the soluble forms of corresponding proteins. Such Fab/scFvs can also be converted into full-length monoclonal antibodies (mAbs) by in-frame cloning of VH and VL genes into the cassette vector that harbors appropriate heavy IgG constant region genes.

In the final step, identified antibodies should be validated for their avidity and affinity against the target antigen via ELISA, western blotting or another immunological assay

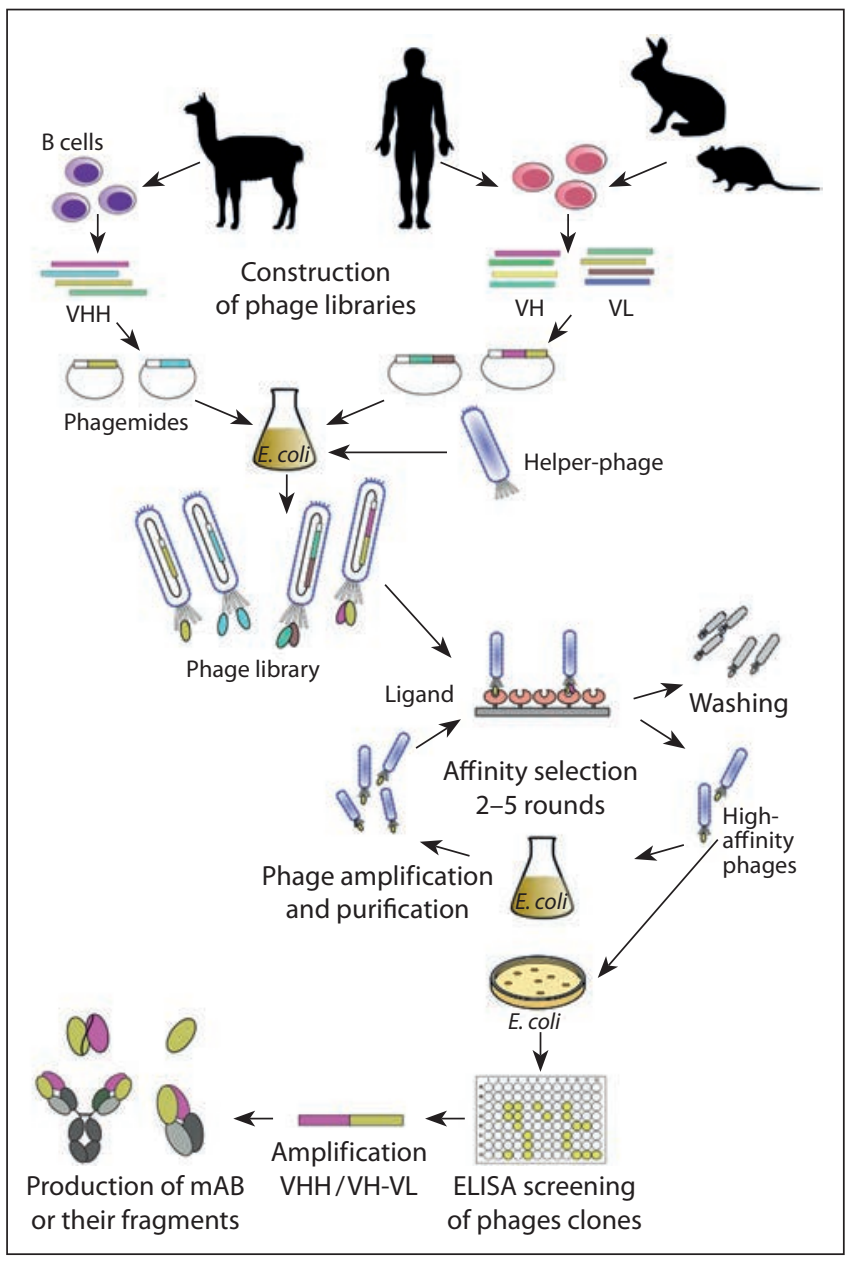

Fig. 1. Scheme representing generation of phage display antibody libraries and biopanning procedure.

(Alfaleh et al., 2020). The general scheme of the method is shown in Fig. 1.

The number of panning rounds can vary depending on whether a greater variety of clones or a greater specificity of fusing to an antigen is required. Additionally, double recognition panning against two antigens can be carried out for the selection of bispecific antibodies (Hammers, Stanley, 2014).

Phage display has plenty of applications: it is used for the development of antibacterial therapeutic agents (Christensen et al., 2001; Huang et al., 2012; Ashby et al., 2017), biosensors (Moon et al., 2019; Sozhamannan, Hofmann, 2020), identification of mAbs for treatment of dermatological, autoimmune diseases or cancers (Chan et al., 2014; Hammers, Stanley, 2014; Nixon et al., 2014; Alfaleh et al., 2020), as a platform for targeted drug and vaccine delivery (Clark, March, 2004; Petrenko, Jayanna, 2014; Nemudraya et al., 2016), as a tool for diagnostics and treatment of viral infections (Castel et al., 2011; Hess, Jewell, 2020). Phage display also has broad applications in the field of HIV-1 research: mapping epitopes recognized by HIV-neutralizing antibodies; searching for HIV-derived peptide mimics, which could be used a fusion inhibitors, components of vaccines 
and diagnostics; identifying HIV-neutralizing antibodies with broad neutralizing activity.

Below we review some examples of identification of HIV-1 broadly neutralizing antibodies using phage display technology.

\section{Broadly neutralizing antibodies}

One of the prominent features of human immunodeficiency virus is its phenomenal ability to evade the humoral immune response by rapidly mutating due to the low fidelity of HIV-1 reverse transcriptase which markedly enhances the genetic variation of the virus and makes it mutate very quickly at the highest rate for any biological entity (Cuevas et al., 2015). Mutations occurring after each cycle of viral replication often cause structural changes in HIV immunodominant regions. As a result, the majority of antibodies elicited against HIV infection are strain-specific, and either are non-neutralizing or lose the ability to neutralize the virus after several replication cycles due to antigen escape. In this regard, it was believed that HIV-1 neutralizing antibodies could not be induced or it occurs extremely rarely (Mccoy, Burton, 2017). Nevertheless, these antibodies were lately found in so-called HIV long-term non-progressors - HIV-infected patients who do not develop immunodeficiency in the absence of antiretroviral therapy. Sera of non-progressors exhibited HIV-neutralizing activity not only against host strains, but also against a panel of different HIV-1 isolates (Dhillon et al., 2007; Walker et al., 2010; Sok, Burton, 2018; Dashti et al., 2019).

It was originally thought that induction of antibodies with broad HIV-1 neutralizing activity is a unique feature of nonprogressors which provide them with the ability to control viremia for a long time (Montefiori et al., 1996). Later, it was shown that bnAbs is elicited in $20-50 \%$ of all HIV-1 infected patients, but it takes a very long time before mature neutralizing antibodies can be arisen: the affinity maturation process may last up to several years from the moment of infection (Doria-Rose et al., 2009; Hraber et al., 2014; Rusert et al., 2016). It was shown that passive administration of a single bnAbs or its combinations to non-human primates completely protected animals against SHIV infection (Hessell et al., 2009; Moldt et al., 2012; Shingai et al., 2014). Moreover, passive transfer of bnAbs to HIV-infected individuals correlated with a long-term viral load reduction to undetectable levels (Lynch et al., 2015; Scheid et al., 2016), and in some cases, a host-protective humoral immune response was formed (Schoofs et al., 2016).

Today, the majority of HIV researchers acknowledge that an immunogen capable of eliciting broadly neutralizing antibodies may provide protection against HIV. Thus, the search for bnAbs and the development of immunogens aimed at elicitation of broadly neutralizing antibodies are among the most important tasks of modern vaccinology.

\section{Phage display as a tool for identification of HIV-1 broadly neutralizing antibodies}

The first studies devoted to the identification of bnAbs using phage display were published in the early 1990s. At that time, there were practically no data on broadly neutralizing antibodies. However, detailed information about the antigenic structure of HIV-1 had already been obtained, which resulted in the understanding that in order to provide effective protection against the virus, the humoral immune response must be targeted to the conserved viral epitopes, which are less susceptible to mutagenesis (Kowalski et al., 1987; Habeshaw et al., 1990; Putney, 1992). These fragments have been considered as the main targets for neutralizing antibodies. Subsequently, other HIV-1 antigenic determinants were discovered, which are critical for the HIV entry into the host cells, also known as sites of vulnerability (Shcherbakov et al., 2015; Kwong, Mascola, 2018). Up to date, at least seven sites on HIV Env that are vulnerable to antibody-mediated protection have been identified (Fig. 2).

\section{bnAbs recognizing conserved regions of the gp120 glycoprotein}

IgG1b12 was the first HIV-1 broadly neutralizing antibody derived using phage display (and also one of the first described bnAbs). In 1991, D.R. Burton et al. obtained an immune Fab library of bacteriophages based on B-cells from the bone marrow of an HIV-positive non-progressor (Barbas et al., 1991; Burton et al., 1991). After the panning of the resulting library against the HIV-1 IIIB gp120 glycoprotein, they selected phage clones that specifically bound with gp120. As a result, specific combinations of VH: VL genes were identified and expressed in the Fab format. It was shown that these Fabs were able to compete with the soluble CD4 molecule (sCD4) for binding to gp120 in ELISA (Burton et al., 1991). In their next work, the authors demonstrated the ability of selected Fabs to neutralize IIIB, MN and RF HIV-1 strains (Barbas et al., 1992).

Expanded screening of the phage library and more detailed analysis revealed a clone displaying the Fab fragment numbered b12, which binds with high affinity to the mature form of gp120 at the CD4bs (Roben et al., 1994). Later, a full-length recombinant IgG1b12 antibody was obtained, which became one of the first HIV-1 broadly neutralizing antibodies discovered (Burton et al., 1994).

Neutralization breadth of IgG1b12 has been repeatedly evaluated using different viral strains and panels of primary HIV-1 isolates. Depending on the panel used, b12 neutralized $30-63 \%$ of the pseudovirus/primary isolates panels used in the experiment (at a concentration of IC50 $<50 \mu \mathrm{g} / \mathrm{ml}$ ), whereas the highest neutralization potency was demonstrated against HIV-1 subtype B (clade B HIV-1) (Burton et al., 1994; Walker et al., 2009; Corti et al., 2010; Wu et al., 2010; Zhang et al., 2012; Gach et al., 2013). Before the advent of the second generation bnAbs, obtained by sorting affinity B-cells memory (Sok, Burton, 2018), among all detected at that time cross-neutralizing antibodies IgG1b12 was one of the leaders in the number of neutralized isolates HIV-1.

\section{bNAbs specific to CD4 binding site}

M.Y. Zhang et al. were the first researchers who identified two CD4bs-specific broadly neutralizing antibodies. They constructed Fab phage immune libraries derived from the bone marrow B-cells of an HIV-infected non-progressor 


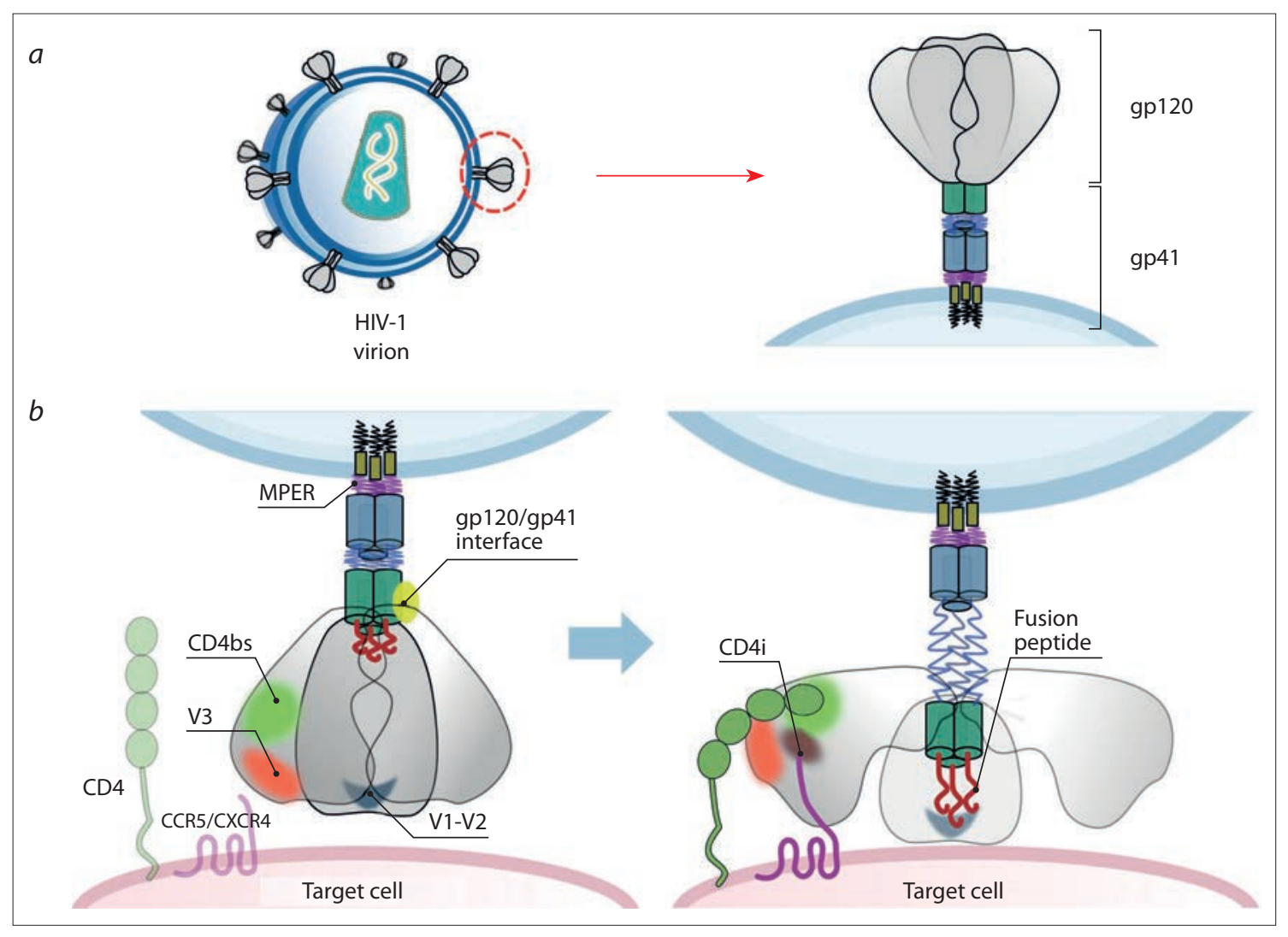

Fig. 2. Sites of HIV-1 vulnerability to bnAbs.

$a$ - schematic representation of HIV-1 envelope glycoprotein (Env). Left - HIV-1 virion structure, right - mature HIV-1 envelope (Env) protein anchored to the viral membrane. Env is a trimer of heterodimers composed of gp41 (transmembrane subunit) and gp120 (surface subunit) molecules; $b$ - conformational changes of HIV-1 Env trimers occurring during infection of host cell. Known HIV-1 sites of vulnerabilities to broadly neutralizing antibodies are indicated: gp120 binding site (CD4bs); V1/V2 glycan apex, loops V3 glycan loop of gp120 (V1/V2, V3); CD4-induced CCR5/CXCR4 binding site which is exposed following CD4 binding (CD4i); gp120/gp41 interface; membraneproximal external region of gp41 (MPER); gp41 N-terminal fusion peptide, which anchors to the host cell membrane.

who had high titers of HIV-1-specific broadly neutralizing antibodies.

In order to identify clones that bind to the conserved antigenic determinants of the virus, biopanning was performed using two antigens. The first round of selection was carried out against sCD4 in complex with recombinant gp140 89.6 a truncation form of gp160 Env of HIV-1 89.6 strain with removed transmembrane and cytoplasmic domains. In the second round, library was panned against HIV-1 IIIB gp140 and SCD4 complex. Subsequent selection rounds were carried out against gp $140_{89.6}$ and gp 140IIIB molecules, respectively, with a gradual decrease in antigen concentration at each round. The binding affinity of the selected clones was evaluated by ELISA using single gp140 ${ }_{89.6} / \mathrm{gp} 140$ IIIB molecules or in complex with sCD4.

The selected $\mathrm{m} 18$ clone showed the highest binding affinity to all of the antigens and was capable of neutralizing 11 out of 15 pseudoviruses bearing HIV-1 Envs from different strains (Zhang et al., 2003). A year later, the selected clones were re-screened by ELISA using the additional JR-FLgp120 antigen, resulting in selection of $\mathrm{m} 14$ Fab clone with enhanced affinity and neutralization breadth compared to $\mathrm{m} 18$ (Zhang et al., 2004a). Next, these clones were tested for neu- tralization activity against extended panel of 30 HIV isolates. It was shown that $\mathrm{m} 14$ and $\mathrm{m} 18$ were able to neutralize about $21-23 \%$ and $13-21 \%$ of a panel, respectively, thereby demonstrating lower neutralization breadth compared to bnAb IgG1b12 (Zhang et al., 2012).

Using a similar approach, the same research group screened a Fab phage library derived from B-cells of R2 donor with high titers of cross-neutralizing antibodies. Two of the identified clones, $\mathrm{m} 22$ and $\mathrm{m} 24$, were expressed as Fab fragments of CD4bs-specific antibodies, which demonstrated neutralization potency and breadth similar to $\mathrm{m} 14$ and m18 (Zhang et al., 2006).

\section{bNAbs specific to CCR5/CXCR4} coreceptor-binding sites of gp120

M. Moulard et al. screened a Fab antibody phage library

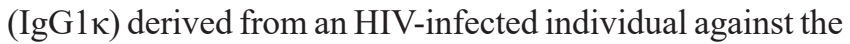
gp120-CD4-CCR5 complex (Moulard et al., 2002). After five rounds of affinity selection, a Fab clone X5 with a unique CDR3 heavy-chain was selected. It was shown that the binding affinity of X5 to the CD4-gp120/CD4-gp140 complexes was significantly higher than that to the single gp 120 and gp140 molecules, respectively. Addition of denatured 
CCR5 to the CD4-gp120 complex increased the X5 affinity, indicating that its epitope is formed by a CD4-dependent conformational change of gp 120 . X5 partially competed for binding to gp120 with other CD4i-specific antibodies, and with CD4bs-recognizing bnAb IgG1b12. Furthermore, X5 Fab neutralized 11 out of 12 primary HIV-1 isolates, thus demonstrating affinity, breadth, and potency comparable to the full-length IgG1b12 (Moulard et al., 2002).

However, the hypothesis that the full-length bivalent variant of IgG X5 would have even greater neutralizing activity was not confirmed. Apparently, the availability of the epitope recognized by X 5 is limited by steric hindrance, which may cause the lack of binding efficacy of the larger molecules (Labrijn et al., 2003; Choudhry et al., 2006). It was thus concluded that the single-chain fragment of this X5 antibody possesses the highest activity and neutralization breadth, compared to its Fab and IgG variants (Choudhry et al., 2006).

Later, non-specific mutagenesis of the $\mathrm{X} 5 \mathrm{scFv}$-encoding sequences was carried out, the resulting "mutant" phage sublibrary was screened against the oligomeric form of gp $140_{89.6}$ (which was non-homologous to gp120JR-FL) in complex with sCD4. Two scFvs, $\mathrm{m} 6$ and $\mathrm{m} 9$, capable of neutralizing 96 and $100 \%$ of primary isolates from a panel comprising 33 different strains, were identified. Moreover, X5 neutralized only $45 \%$ of the isolates from this panel (Zhang et al., $2004 b)$. Neutralization assay performed using another panel of $30 \mathrm{HIV}-1$ different strains revealed that $\mathrm{m} 9$ neutralized $76 \%$ of the primary isolates (Zhang et al., 2012).

\section{bNabs specific to the MPER region of the gp41 glycoprotein}

Another site of vulnerability of HIV-1, the membrane-proximal outer region of the gp41 glycoprotein (MPER), which is located between the transmembrane region and the gp41 C-terminal $\alpha$-helical fragment, became another target of HIV bnAbs. Since MPER plays a crucial role in the process of viral fusion to the target cell, it is highly conservative and thus considered as one of the most promising targets for the development of antiviral drugs (Burton, Hangartner, 2016). The study performed by M. Zwick and his colleagues (2001) should be mentioned as one of the first attempts to search for MPER-specific bnAbs using phage display. They developed an immune Fab phage library based on cDNA of VH/VL genes isolated from the B cells of the bone marrow of an HIV-1 non-progressor who had a high titer of broadly neutralizing antibodies.

Two biopanning strategies were applied: in the first case, the HIV-1MN gp41 peptide MN 2031 comprising the MPER sequence was used as an antigen. In the second, the selection was carried out against a whole HIV-1MN virion. After the panning, several MPER-specific clones were identified, including Fab Z13 clone which had the highest affinity and neutralization breadth. Next, the authors created a "mutant" phage library displaying Fab Z13 with random mutations in the LCDR3 and screened it against the gp41 glycoprotein, in order to identify the Z13 clones with enhanced affinity. Among the selected phages, clone exposing Fab Z13e1 bound to gp41 MPER with the highest affinity. Subsequently, a full-length Z13e1 IgG molecule was obtained, which provided a more-than-100-fold enhanced affinity for binding to MPER, and a significant increase in HIV-1-neutralizing activity compared to the initial IgG Z13 variant. The amount of neutralized isolates increased from 35 to $50 \%$ (Zwick et al., 2001; Nelson et al., 2007).

\section{bNabs recognizing the gp120-gp41 interface}

Phage display was also used for identification of bnAbs that bind to the N-terminal domain of gp41, the so-called fusion peptide (see Fig. 2). Antibodies are able to bind to gp41 after conformational changes occurring during the last stages of HIV cell entry.

Such anti-gp41 antibodies were first described by M. Miller's research group (Miller et al., 2005). They used B-cells from the bone marrow of an HIV-negative patient for naive $\mathrm{scFv}$ phage library construction and subsequent identification of human monoclonal antibodies specific to the gp41 N-terminal region (NHR). The library was subsequently panned against the polymer that mimics gp416 HB peptide complex, and then against the IZN36 peptide mimetic of the N-terminal heptad repeats (NHR). As a result, both antigen-binding phage clones were selected and used for reconstruction of corresponding soluble scFvs and full-length IgGs. Virus neutralization assay led to the detection of H/I1-BMV-D5 antibody capable of neutralizing 9 of 19 tested HIV-1 isolates (Miller et al., 2005).

\section{Searching for bnAbs using phage display of single domain antibody fragments}

In addition to the "classical" scFv/Fab phage display, phage libraries based on camelid single domain antibodies (nanobodies) were used to search for HIV bnAbs (see Fig. 1). Compared to IgG, nanobodies are more stable and have a smaller size, which can be beneficial for binding to sterically restricted antigenic determinants. Besides, the absence of light chains in the VHH structure facilitates gene manipulations and cloning procedures during library construction.

One of the first immune VHH phage libraries was obtained from llamas immunized with trimeric form of HIV-1 gp140 derived from a clade C (CN54). Total RNA of lymphocytes was isolated and used for cDNA synthesis; the repertoire of VHH genes was amplified and cloned into a phagemid vector, obtaining a library of phages displaying HIV-specific VHHs as pIII fusion proteins. Biopanning of the library led to the isolation of $\mathrm{VHH} \mathrm{A} 12, \mathrm{C} 8$ and D7 that were able to neutralize 24 and 26 of 65 HIV-1 Env-pseudotyped virions from tier 1, 2, and 3 of various isolates (Forsman et al., 2008). Similarly, a phagemid immune library based on a VHH from llama immunized with clades A and B/C HIV-1 gp140 was obtained. After the biopanning, J3 and 3E3 clones were identified, which bound specifically to CD4bs and were able to neutralize 96 and $95 \%$ of the pseudovirus panel (Mccoy et al., 2012, 2014; Strokappe et al., 2012).

Later, the same library was used for selection of VHH clones that were specific to the other HIV-1 glycoproteins: 
1F10, which binds to the V3 loop of gp 120; 1B5, which recognizes the CCR 5 binding region, gp 41 -specific $2 \mathrm{H} 10$ and 2E7 clones. These nanobodies were capable of neutralizing from 45 to $80 \%$ of Env pseudoviruses from the panels used (Lutje Hulsik et al., 2013; Strokappe et al., 2019). Bivalent nanobodies carrying VHHs with the highest neutralizing activity were also designed. The neutralization potency of these bispecific nanobodies increased approximately 1400fold compared to the mixture of the individual VHHs; the highest efficiency of the nanobodies was observed against clade C HIV-1 viral strains (Lutje Hulsik et al., 2013; Strokappe et al., 2019).

K. Koch and colleagues (2017) separately prepared a phage immune library of HIV-specific VHHs using lymphocytes of camel immunized with soluble stabilized HIV-1 clade C gp140 Env trimer (SOSIP gp140). After affinity selection of the library, several CD4bs-specific nanobodies were identified, the best of which (VHH-9, VHH-28, VHH-A6) were capable of neutralizing 53,65 , and $77 \%$ of a 21 -isolate HIV-1 Env pseudovirus panel.

The authors of the above-mentioned studies emphasize that display of nanobody immune libraries via phage display is a convenient and effective alternative to the "traditional" $\mathrm{scFv} / \mathrm{Fab}$ libraries for searching for high-affinity HIV-1 broadly-neutralizing antibodies. Small size and chemical stability of VHH facilitate various genetic manipulations directed to obtain clones with improved characteristics, such as site-targeted mutagenesis or creation of humanized and multivalent nanobodies specific to different regions of viral antigens. Finally, VHH phage libraries may be considered as a cheaper-to-manufacture alternative to full-sized human MAbs for HIV treatment (Weiss, Verrips, 2019).

\section{Conclusion}

Phage display technology played an essential role as a tool for searching, studying and epitope mapping of HIV-neutralizing antibodies. Phage display yielded the first HIV-1 bnAb, thereby leading to the extensive development of this research area. Soon, broadly neutralizing antibodies became a major focus of HIV vaccine design. Current methods for isolating HIV-specific bnAbs include the sorting of antigen-specific $\mathrm{B}$ cells with one memory on virus-like particles or variable loop removed recombinant viral proteins (Wu et al., 2010). These techniques, along with high-throughput screening of selected antibody clones (Walker et al., 2009), allowed the identification of second-generation HIV-1 bnAbs with markedly increased potency and breadth. The discovery of such antibodies capable of neutralizing more than $90 \%$ of viral isolates has reinvigorated interest in the use of bnAbs in HIV-1 therapy.

Since 2010, more than 30 clinical trials of broadly neutralizing antibodies have been registered (Mahomed et al., 2021). Among them, 12 studies successfully passed Phase I, demonstrating safety of bnAbs and their combinations; four Phase II bnAb trials are currently underway, first data are expected to be made publicly available in 2021 (Julg, Barouch, 2019; Karuna, Corey, 2020; Mahomed et al., 2020;
Stephenson et al., 2020). Lastly, relying on the progress achieved in generating recombinant viral antigens (Jardine et al., 2013; Medina-Ramirez et al., 2017; Stamatatos et al., 2017; Duan et al., 2018), together with a vast amount of data accumulated on broadly neutralizing antibodies (Mascola, Haynes, 2013; Mouquet, Nussenzweig, 2013), novel strategies for design of HIV vaccines aimed for induction of 2nd generation bnAbs have been proposed (Del Moral-Sanchez, Sliepen, 2019).

Hence, bNAbs represent a promising novel approach for effective HIV-1 immunotherapy and prevention. Thus, today bnAbs are one of the most important objects in the study of HIV infection. It is likely that in the foreseeable future they will become a worthy alternative to existing antiretroviral therapy, and in the longer term, one can expect the emergence of preventive vaccines that induce their production.

\section{References}

Alfaleh M.A., Alsaab H.O., Mahmoud A.B., Alkayyal A.A., Jones M.L., Mahler S.M., Hashem A.M. Phage display derived monoclonal antibodies: from bench to bedside. Front. Immunol. 2020;11:1986. DOI 10.3389/fimmu.2020.01986.

Ashby M., Petkova A., Gani J., Mikut R., Hilpert K. Use of peptide libraries for identification and optimization of novel antimicrobial peptides. Curr. Top. Med. Chem. 2017;17(5):537-553. DOI 10.2174/ 1568026616666160713125555

Barbas C.F., 3rd, Crowe J.E., Jr., Cababa D., Jones T.M., Zebedee S.L., Murphy B.R., Chanock R.M., Burton D.R. Human monoclonal Fab fragments derived from a combinatorial library bind to respiratory syncytial virus F glycoprotein and neutralize infectivity. Proc. Natl. Acad. Sci. USA. 1992;89(21):10164-10168. DOI 10.1073/pnas.89. 21.10164.

Barbas C.F., 3rd, Kang A.S., Lerner R.A., Benkovic S.J. Assembly of combinatorial antibody libraries on phage surfaces: the gene III site. Proc. Natl. Acad. Sci. USA. 1991;88(18):7978-7982. DOI 10.1073/ pnas.88.18.7978.

Burton D.R., Barbas C.F., 3rd, Persson M.A., Koenig S., Chanock R.M., Lerner R.A. A large array of human monoclonal antibodies to type 1 human immunodeficiency virus from combinatorial libraries of asymptomatic seropositive individuals. Proc. Natl. Acad. Sci. USA. 1991;88(22):10134-10137. DOI 10.1073/pnas.88.22.10134.

Burton D.R., Hangartner L. Broadly neutralizing antibodies to HIV and their role in vaccine design. Annu. Rev. Immunol. 2016;34:635-659. DOI 10.1146/annurev-immunol-041015-055515.

Burton D.R., Pyati J., Koduri R., Sharp S.J., Thornton G.B., Parren P.W., Sawyer L.S., Hendry R.M., Dunlop N., Nara P.L. Efficient neutralization of primary isolates of HIV-1 by a recombinant human monoclonal antibody. Science. 1994;266(5187):1024-1027. DOI 10.1126/science.7973652.

Castel G., Chteoui M., Heyd B., Tordo N. Phage display of combinatorial peptide libraries: application to antiviral research. Molecules. 2011;16(5):3499-3518. DOI 10.3390/molecules16053499.

Chames P., Baty D. Phage display and selections on biotinylated antigens. In: Kotermann R., Dübel S. (Eds.). Antibody Engineering. Humana Press, 2010;151-164. DOI 10.1007/978-3-642-01144-3 11.

Chan C.E., Lim A.P., Macary P.A., Hanson B.J. The role of phage display in therapeutic antibody discovery. Int. Immunol. 2014;26(12): 649-657. DOI 10.1093/intimm/dxu082.

Choudhry V., Zhang M.Y., Dimitrova D., Prabakaran P., Dimitrov A.S., Fouts T.R., Dimitrov D.S. Antibody-based inhibitors of HIV infection. Expert Opin. Biol. Ther. 2006;6(5):523-531. DOI 10.1517/ 14712598.6.5.523. 
Christensen D.J., Gottlin E.B., Benson R.E., Hamilton P.T. Phage display for target-based antibacterial drug discovery. Drug Discov. Today. 2001;6(14):721-727. DOI 10.1016/s1359-6446(01)01853-0.

Clackson T., Hoogenboom H.R., Griffiths A.D., Winter G. Making antibody fragments using phage display libraries. Nature. 1991; 352(6336):624-628. DOI 10.1038/352624a0.

Clark J.R., March J.B. Bacteriophage-mediated nucleic acid immunisation. FEMS Immunol. Med. Microbiol. 2004;40(1):21-26. DOI 10.1016/S0928-8244(03)00344-4.

Corti D., Langedijk J.P., Hinz A., Seaman M.S., Vanzetta F., FernandezRodriguez B.M., Silacci C., Pinna D., Jarrossay D., Balla-Jhagjhoorsingh S., Willems B., Zekveld M.J., Dreja H., O'sullivan E., Pade C., Orkin C., Jeffs S.A., Montefiori D.C., Davis D., Weissenhorn W., Mcknight A., Heeney J.L., Sallusto F., Sattentau Q.J., Weiss R.A., Lanzavecchia A. Analysis of memory B cell responses and isolation of novel monoclonal antibodies with neutralizing breadth from HIV-1-infected individuals. PLoS One. 2010;5(1):e8805. DOI 10.1371/journal.pone.0008805.

Cuevas J.M., Geller R., Garijo R., Lopez-Aldeguer J., Sanjuan R. Extremely high mutation rate of HIV-1 in vivo. PLoS Biol. 2015;13(9): e1002251. DOI 10.1371/journal.pbio.1002251.

Dashti A., Devico A.L., Lewis G.K., Sajadi M.M. Broadly neutralizing antibodies against HIV: back to blood. Trends Mol. Med. 2019; 25(3):228-240. DOI 10.1016/j.molmed.2019.01.007.

Davies J., Riechmann L. Antibody VH domains as small recognition units. Biotechnology (NY). 1995;13(5):475-479. DOI 10.1038/nbt 0595-475.

Del Moral-Sanchez I., Sliepen K. Strategies for inducing effective neutralizing antibody responses against HIV-1. Expert Rev. Vaccines. 2019;18(11):1127-1143. DOI 10.1080/14760584.2019.1690458.

Dhillon A.K., Donners H., Pantophlet R., Johnson W.E., Decker J.M., Shaw G.M., Lee F.H., Richman D.D., Doms R.W., Vanham G., Burton D.R. Dissecting the neutralizing antibody specificities of broadly neutralizing sera from human immunodeficiency virus type 1-infected donors. J. Virol. 2007;81(12):6548-6562. DOI 10.1128/JVI. 02749-06.

Doria-Rose N.A., Klein R.M., Manion M.M., O'dell S., Phogat A., Chakrabarti B., Hallahan C.W., Migueles S.A., Wrammert J., Ahmed R., Nason M., Wyatt R.T., Mascola J.R., Connors M. Frequency and phenotype of human immunodeficiency virus envelope-specific B cells from patients with broadly cross-neutralizing antibodies. J. Virol. 2009;83(1):188-199. DOI 10.1128/JVI. 01583-08.

Duan H., Chen X., Boyington J.C., Cheng C., Zhang Y., Jafari A.J., Stephens T., Tsybovsky Y., Kalyuzhniy O., Zhao P., Menis S., Nason M.C., Normandin E., Mukhamedova M., Dekosky B.J., Wells L., Schief W.R., Tian M., Alt F.W., Kwong P.D., Mascola J.R. Glycan masking focuses immune responses to the HIV-1 CD4-binding site and enhances elicitation of VRC01-class precursor antibodies. Immunity. 2018;49(2):301-311 e305. DOI 10.1016/j.immuni.2018. 07.005 .

Felici F., Castagnoli L., Musacchio A., Jappelli R., Cesareni G. Selection of antibody ligands from a large library of oligopeptides expressed on a multivalent exposition vector. J. Mol. Biol. 1991;222(2):301310. DOI 10.1016/0022-2836(91)90213-p.

Forsman A., Beirnaert E., Aasa-Chapman M.M., Hoorelbeke B., Hijazi K., Koh W., Tack V., Szynol A., Kelly C., Mcknight A., Verrips T., De Haard H., Weiss R.A. Llama antibody fragments with crosssubtype human immunodeficiency virus type 1 (HIV-1)-neutralizing properties and high affinity for HIV-1 gp120. J. Virol. 2008;82(24): 12069-12081. DOI 10.1128/JVI.01379-08.

Gach J.S., Quendler H., Tong T., Narayan K.M., Du S.X., Whalen R.G., Binley J.M., Forthal D.N., Poignard P., Zwick M.B. A human antibody to the CD4 binding site of gp120 capable of highly potent but sporadic cross clade neutralization of primary HIV-1. PLoS One. 2013;8(8):e72054. DOI 10.1371/journal.pone.0072054.

Greenberg A.S., Avila D., Hughes M., Hughes A., McKinney E.C., Flajnik M.F. A new antigen receptor gene family that undergoes rearrangement and extensive somatic diversification in sharks. Nature. 1995;374(6518):168-173. DOI 10.1038/374168a0.

Griffiths A.D., Duncan A.R. Strategies for selection of antibodies by phage display. Curr. Opin. Biotechnol. 1998;9(1):102-108. DOI 10.1016/s0958-1669(98)80092-x.

Habeshaw J.A., Dalgleish A.G., Bountiff L., Newell A.L., Wilks D., Walker L.C., Manca F. AIDS pathogenesis: HIV envelope and its interaction with cell proteins. Immunol. Today. 1990;11(11):418-425. DOI 10.1016/0167-5699(90)90162-3.

Hammers C.M., Stanley J.R. Antibody phage display: technique and applications. J. Invest. Dermatol. 2014;134(2):1-5. DOI 10.1038/jid. 2013.521.

Hess K.L., Jewell C.M. Phage display as a tool for vaccine and immunotherapy development. Bioeng. Transl. Med. 2020;5(1):e10142. DOI 10.1002/btm2.10142.

Hessell A.J., Rakasz E.G., Poignard P., Hangartner L., Landucci G., Forthal D.N., Koff W.C., Watkins D.I., Burton D.R. Broadly neutralizing human anti-HIV antibody $2 \mathrm{G} 12$ is effective in protection against mucosal SHIV challenge even at low serum neutralizing titers. PLoS Pathog. 2009;5(5):e1000433. DOI 10.1371/journal.ppat. 1000433

Hraber P., Korber B.T., Lapedes A.S., Bailer R.T., Seaman M.S., Gao H., Greene K.M., Mccutchan F., Williamson C., Kim J.H., Tovanabutra S., Hahn B.H., Swanstrom R., Thomson M.M., Gao F., Harris L., Giorgi E., Hengartner N., Bhattacharya T., Mascola J.R., Montefiori D.C. Impact of clade geography and age of the epidemic on HIV-1 neutralization by antibodies. J. Virol. 2014;88(21):1262312643. DOI 10.1128/JVI.01705-14.

Huang J.X., Bishop-Hurley S.L., Cooper M.A. Development of antiinfectives using phage display: biological agents against bacteria viruses and parasites. Antimicrob. Agents Chemother. 2012;56(9): 4569-4582. DOI 10.1128/AAC.00567-12.

Ilyichev A.A., Minenkova O.O., Kishchenko G.P., Tat'kov S.I., Karpishev N.N., Eroshkin A.M., Ofitzerov V.I., Akimenko Z.A., Petrenko V.A., Sandakhchiev L.S. Inserting foreign peptides into the major coat protein of bacteriophage M13. FEBS Lett. 1992;301(3):322324. DOI 10.1016/0014-5793(92)80267-k

Jardine J., Julien J.P., Menis S., Ota T., Kalyuzhniy O., Mcguire A., Sok D., Huang P.S., Macpherson S., Jones M., Nieusma T., Mathison J., Baker D., Ward A.B., Burton D.R., Stamatatos L., Nemazee D., Wilson I.A., Schief W.R. Rational HIV immunogen design to target specific germline B cell receptors. Science. 2013;340(6133):711716. DOI 10.1126/science. 1234150

Julg B., Barouch D.H. Neutralizing antibodies for HIV-1 prevention. Curr. Opin. HIV AIDS. 2019;14(4):318-324. DOI 10.1097/COH. 0000000000000556

Karuna S.T., Corey L. Broadly neutralizing antibodies for HIV prevention. Annu. Rev. Med. 2020;71(1):329-346. DOI 10.1146/annurevmed-110118-045506.

Kay B.K., Adey N.B., He Y.S., Manfredi J.P., Mataragnon A.H., Fowlkes D.M. An M13 phage library displaying random 38-amino-acid peptides as a source of novel sequences with affinity to selected targets. Gene. 1993;128(1):59-65. DOI 10.1016/0378-1119(93)90153-t.

Kennedy P.J., Oliveira C., Granja P.L., Sarmento B. Monoclonal antibodies: technologies for early discovery and engineering. Crit. Rev. Biotechnol. 2018;38(3):394-408. DOI 10.1080/07388551.2017.135 7002.

Kishchenko G., Batliwala H., Makowski L. Structure of a foreign peptide displayed on the surface of bacteriophage M13. J. Mol. Biol. 1994;241(2):208-213. DOI 10.1006/jmbi.1994.1489. 
Koch K., Kalusche S., Torres J.L., Stanfield R.L., Danquah W., Khazanehdari K., Von Briesen H., Geertsma E.R., Wilson I.A., Wernery U., Koch-Nolte F., Ward A.B., Dietrich U. Selection of nanobodies with broad neutralizing potential against primary HIV-1 strains using soluble subtype C gp140 envelope trimers. Sci. Rep. 2017;7(1):8390. DOI 10.1038/s41598-017-08273-7.

Kowalski M., Potz J., Basiripour L., Dorfman T., Goh W.C., Terwilliger E., Dayton A., Rosen C., Haseltine W., Sodroski J. Functional regions of the envelope glycoprotein of human immunodeficiency virus type 1. Science. 1987;237(4820):1351-1355. DOI 10.1126/ science.3629244.

Kwong P.D., Mascola J.R. HIV-1 vaccines based on antibody identification B cell ontogeny and epitope structure. Immunity. 2018;48(5): 855-871. DOI 10.1016/j.immuni.2018.04.029.

Labrijn A.F., Poignard P., Raja A., Zwick M.B., Delgado K., Franti M., Binley J., Vivona V., Grundner C., Huang C.C., Venturi M., Petropoulos C.J., Wrin T., Dimitrov D.S., Robinson J., Kwong P.D., Wyatt R.T., Sodroski J., Burton D.R. Access of antibody molecules to the conserved coreceptor binding site on glycoprotein gp120 is sterically restricted on primary human immunodeficiency virus type 1 . J. Virol. 2003;77(19):10557-10565. DOI 10.1128/jvi.77.19.1055710565.2003

Ledsgaard L., Kilstrup M., Karatt-Vellatt A., McCafferty J., Laustsen A.H. Basics of antibody phage display technology. Toxins (Basel). 2018;10(6). DOI 10.3390/toxins10060236.

Lutje Hulsik D., Liu Y.Y., Strokappe N.M., Battella S., El Khattabi M., Mccoy L.E., Sabin C., Hinz A., Hock M., Macheboeuf P., Bonvin A.M., Langedijk J.P., Davis D., Forsman Quigley A., AasaChapman M.M., Seaman M.S., Ramos A., Poignard P., Favier A., Simorre J.P., Weiss R.A., Verrips C.T., Weissenhorn W., Rutten L. A gp41 MPER-specific llama VHH requires a hydrophobic CDR3 for neutralization but not for antigen recognition. PLoS Pathog. 2013;9(3):e1003202. DOI 10.1371/journal.ppat.1003202.

Lynch R.M., Boritz E., Coates E.E., Dezure A., Madden P., Costner P., Enama M.E., Plummer S., Holman L., Hendel C.S., Gordon I., Casazza J., Conan-Cibotti M., Migueles S.A., Tressler R., Bailer R.T., Mcdermott A., Narpala S., O'dell S., Wolf G., Lifson J.D., Freemire B.A., Gorelick R.J., Pandey J.P., Mohan S., Chomont N., Fromentin R., Chun T.W., Fauci A.S., Schwartz R.M., Koup R.A., Douek D.C., Hu Z., Capparelli E., Graham B.S., Mascola J.R., Ledgerwood J.E., VRC 601 Study Team. Virologic effects of broadly neutralizing antibody VRC01 administration during chronic HIV-1 infection. Sci. Transl. Med. 2015;7(319):319ra206. DOI 10.1126/ scitranslmed.aad5752.

Mahomed S., Garrett N., Baxter C., Abdool Karim Q., Abdool Karim S.S. Clinical trials of broadly neutralizing monoclonal antibodies for Human Immunodeficiency Virus prevention: a review. J. Infect. Dis. 2021;223(3):370-380. DOI 10.1093/infdis/jiaa377.

Mahomed S., Garrett N., Karim Q.A., Zuma N.Y., Capparelli E., Baxter C., Gengiah T., Archary D., Samsunder N., Rose N.D., Moore P., Williamson C., Barouch D.H., Fast P.E., Pozzetto B., Hankins C., Carlton K., Ledgerwood J., Morris L., Mascola J., Abdool Karim S. Assessing the safety and pharmacokinetics of the anti-HIV monoclonal antibody CAP256V2LS alone and in combination with VRC07-523LS and PGT121 in South African women: study protocol for the first-in-human CAPRISA 012B phase I clinical trial. BMJ Open. 2020;10(11):e042247. DOI 10.1136/bmjopen-2020-042247.

Mascola J.R., Haynes B.F. HIV-1 neutralizing antibodies: understanding nature's pathways. Immunol. Rev. 2013;254(1):225-244. DOI 10.1111/imr.12075.

McCafferty J., Griffiths A.D., Winter G., Chiswell D.J. Phage antibodies: filamentous phage displaying antibody variable domains. Nature. 1990;348(6301):552-554. DOI 10.1038/348552a0.

Mccoy L.E., Burton D.R. Identification and specificity of broadly neutralizing antibodies against HIV. Immunol. Rev. 2017;275(1):11-20. DOI 10.1111/imr.12484.
Mccoy L.E., Quigley A.F., Strokappe N.M., Bulmer-Thomas B., Seaman M.S., Mortier D., Rutten L., Chander N., Edwards C.J., Ketteler R., Davis D., Verrips T., Weiss R.A. Potent and broad neutralization of HIV-1 by a llama antibody elicited by immunization. J. Exp. Med. 2012;209(6):1091-1103. DOI 10.1084/jem.20112655.

Mccoy L.E., Rutten L., Frampton D., Anderson I., Granger L., Bashford-Rogers R., Dekkers G., Strokappe N.M., Seaman M.S., Koh W., Grippo V., Kliche A., Verrips T., Kellam P., Fassati A., Weiss R.A. Molecular evolution of broadly neutralizing llama antibodies to the CD4-binding site of HIV-1. PLoS Pathog. 2014;10(12):e1004552. DOI 10.1371/journal.ppat.1004552.

Medina-Ramirez M., Garces F., Escolano A., Skog P., De Taeye S.W., Del Moral-Sanchez I., Mcguire A.T., Yasmeen A., Behrens A.J., Ozorowski G., Van Den Kerkhof T., Freund N.T., Dosenovic P., Hua Y., Gitlin A.D., Cupo A., Van Der Woude P., Golabek M., Sliepen K., Blane T., Kootstra N., Van Breemen M.J., Pritchard L.K., Stanfield R.L., Crispin M., Ward A.B., Stamatatos L., Klasse P.J., Moore J.P., Nemazee D., Nussenzweig M.C., Wilson I.A., Sanders R.W. Design and crystal structure of a native-like HIV-1 envelope trimer that engages multiple broadly neutralizing antibody precursors in vivo. J. Exp. Med. 2017;214(9):2573-2590. DOI 10.1084/ jem.20161160.

Miller M.D., Geleziunas R., Bianchi E., Lennard S., Hrin R., Zhang H., Lu M., An Z., Ingallinella P., Finotto M., Mattu M., Finnefrock A.C., Bramhill D., Cook J., Eckert D.M., Hampton R., Patel M., Jarantow S., Joyce J., Ciliberto G., Cortese R., Lu P., Strohl W., Schleif W., Mcelhaugh M., Lane S., Lloyd C., Lowe D., Osbourn J., Vaughan T., Emini E., Barbato G., Kim P.S., Hazuda D.J., Shiver J.W., Pessi A. A human monoclonal antibody neutralizes diverse HIV-1 isolates by binding a critical gp41 epitope. Proc. Natl. Acad. Sci. USA. 2005; 102(41):14759-14764. DOI 10.1073/pnas.0506927102.

Minenkova O.O., Ilyichev A.A., Kishchenko G.P., Petrenko V.A. Design of specific immunogens using filamentous phage as the carrier. Gene. 1993;128(1):85-88. DOI 10.1016/0378-1119(93) 90157-x.

Moldt B., Rakasz E.G., Schultz N., Chan-Hui P.Y., Swiderek K., Weisgrau K.L., Piaskowski S.M., Bergman Z., Watkins D.I., Poignard P., Burton D.R. Highly potent HIV-specific antibody neutralization in vitro translates into effective protection against mucosal SHIV challenge in vivo. Proc. Natl. Acad. Sci. USA. 2012;109(46):1892118925. DOI 10.1073/pnas.1214785109.

Montefiori D.C., Baba T.W., Li A., Bilska M., Ruprecht R.M. Neutralizing and infection-enhancing antibody responses do not correlate with the differential pathogenicity of SIVmac239delta3 in adult and infant rhesus monkeys. J. Immunol. 1996;157(12):5528-5535.

Moon J.S., Choi E.J., Jeong N.N., Sohn J.R., Han D.W., Oh J.W. Research progress of M13 bacteriophage-based biosensors. Nanomaterials (Basel). 2019;9(10). DOI 10.3390/nano9101448.

Moulard M., Phogat S.K., Shu Y., Labrijn A.F., Xiao X., Binley J.M., Zhang M.Y., Sidorov I.A., Broder C.C., Robinson J., Parren P.W., Burton D.R., Dimitrov D.S. Broadly cross-reactive HIV-1-neutralizing human monoclonal Fab selected for binding to gp120-CD4CCR5 complexes. Proc. Natl. Acad. Sci. USA. 2002;99(10):69136918. DOI 10.1073/pnas.102562599.

Mouquet H., Nussenzweig M.C. HIV: Roadmaps to a vaccine. Nature. 2013;496(7446):441-442. DOI 10.1038/nature12091.

Mullen L.M., Nair S.P., Ward J.M., Rycroft A.N., Henderson B. Phage display in the study of infectious diseases. Trends Microbiol. 2006; 14(3):141-147. DOI 10.1016/j.tim.2006.01.006.

Muyldermans S. A guide to: generation and design of nanobodies. FEBS J. 2021;288(7):2084-2102. DOI 10.1111/febs.15515.

Nelson J.D., Brunel F.M., Jensen R., Crooks E.T., Cardoso R.M., Wang M., Hessell A., Wilson I.A., Binley J.M., Dawson P.E., Burton D.R., Zwick M.B. An affinity-enhanced neutralizing antibody against the membrane-proximal external region of human immunodeficiency virus type 1 gp41 recognizes an epitope between those 
of 2F5 and 4E10. J. Virol. 2007;81(8):4033-4043. DOI 10.1128/ JVI.02588-06.

Nemudraya A.A., Richter V.A., Kuligina E.V. Phage peptide libraries as a source of targeted ligands. Acta Naturae. 2016;8(1):48-57. DOI 10.32607/20758251-2016-8-1-48-57.

Nixon A.E., Sexton D.J., Ladner R.C. Drugs derived from phage display: from candidate identification to clinical practice. MAbs. 2014; 6(1):73-85. DOI 10.4161/mabs.27240.

Petrenko V.A., Jayanna P.K. Phage protein-targeted cancer nanomedicines. FEBS Lett. 2014;588(2):341-349. DOI 10.1016/j.febslet. 2013.11.011.

Putney S. How antibodies block HIV infection: paths to an AIDS vaccine. Trends Biochem. Sci. 1992;17(5):191-196. DOI 10.1016/09680004(92)90265-b.

Roben P., Moore J.P., Thali M., Sodroski J., Barbas C.F., 3rd, Burton D.R. Recognition properties of a panel of human recombinant Fab fragments to the CD4 binding site of gp120 that show differing abilities to neutralize human immunodeficiency virus type 1 . J. Virol. 1994;68(8):4821-4828. DOI 10.1128/JVI.68.8.4821-4828. 1994.

Rusert P., Kouyos R.D., Kadelka C., Ebner H., Schanz M., Huber M., Braun D.L., Hoze N., Scherrer A., Magnus C., Weber J., Uhr T., Cippa V., Thorball C.W., Kuster H., Cavassini M., Bernasconi E., Hoffmann M., Calmy A., Battegay M., Rauch A., Yerly S., Aubert V., Klimkait T., Boni J., Fellay J., Regoes R.R., Gunthard H.F., Trkola A., Swiss Hives T. Determinants of HIV-1 broadly neutralizing antibody induction. Nat. Med. 2016;22(11):1260-1267. DOI 10.1038/nm.4187.

Scheid J.F., Horwitz J.A., Bar-On Y., Kreider E.F., Lu C.L., Lorenzi J.C., Feldmann A., Braunschweig M., Nogueira L., Oliveira T., Shimeliovich I., Patel R., Burke L., Cohen Y.Z., Hadrigan S., Settler A., Witmer-Pack M., West A.P., Jr., Juelg B., Keler T., Hawthorne T., Zingman B., Gulick R.M., Pfeifer N., Learn G.H., Seaman M.S., Bjorkman P.J., Klein F., Schlesinger S.J., Walker B.D., Hahn B.H., Nussenzweig M.C., Caskey M. HIV-1 antibody 3BNC117 suppresses viral rebound in humans during treatment interruption. Nature. 2016;535(7613):556-560. DOI 10.1038/nature18929.

Schoofs T., Klein F., Braunschweig M., Kreider E.F., Feldmann A., Nogueira L., Oliveira T., Lorenzi J.C., Parrish E.H., Learn G.H., West A.P., Jr., Bjorkman P.J., Schlesinger S.J., Seaman M.S., Czartoski J., Mcelrath M.J., Pfeifer N., Hahn B.H., Caskey M., Nussenzweig M.C. HIV-1 therapy with monoclonal antibody 3BNC117 elicits host immune responses against HIV-1. Science. 2016; 352(6288):997-1001. DOI 10.1126/science.aaf0972.

Scott J.K., Smith G.P. Searching for peptide ligands with an epitope library. Science. 1990;249(4967):386-390. DOI 10.1126/science. 1696028.

Shcherbakov D.N., Bakulina A.Y., Karpenko L.I., Ilyichev A.A. Broadly neutralizing antibodies against HIV-1 as a novel aspect of the immune response. Acta Naturae. 2015;7(4):11-21.

Shingai M., Donau O.K., Plishka R.J., Buckler-White A., Mascola J.R., Nabel G.J., Nason M.C., Montefiori D., Moldt B., Poignard P., Diskin R., Bjorkman P.J., Eckhaus M.A., Klein F., Mouquet H., Cetrulo Lorenzi J.C., Gazumyan A., Burton D.R., Nussenzweig M.C., Martin M.A., Nishimura Y. Passive transfer of modest titers of potent and broadly neutralizing anti-HIV monoclonal antibodies block SHIV infection in macaques. J. Exp. Med. 2014;211(10):2061-2074. DOI 10.1084/jem.20132494.

Skerra A., Pluckthun A. Assembly of a functional immunoglobulin Fv fragment in Escherichia coli. Science. 1988;240(4855):1038-1041. DOI 10.1126/science.3285470.

Smith G.P. Filamentous fusion phage: novel expression vectors that display cloned antigens on the virion surface. Science. 1985; 228(4705):1315-1317. DOI 10.1126/science.4001944.
Smith G.P., Petrenko V.A. Phage display. Chem. Rev. 1997;97(2):391410. DOI 10.1021/cr960065d.

Sok D., Burton D.R. Recent progress in broadly neutralizing antibodies to HIV. Nat. Immunol. 2018;19(11):1179-1188. DOI 10.1038/ s41590-018-0235-7.

Sozhamannan S., Hofmann E.R. The state of the art in biodefense related bacterial pathogen detection using bacteriophages: how it started and how it's going. Viruses. 2020;12(12). DOI 10.3390/v121 21393.

Stamatatos L., Pancera M., Mcguire A.T. Germline-targeting immunogens. Immunol. Rev. 2017;275(1):203-216. DOI 10.1111/imr. 12483.

Stephenson K.E., Wagh K., Korber B., Barouch D.H. Vaccines and broadly neutralizing antibodies for HIV-1 prevention. Annu. Rev. Immunol. 2020;38(673-703). DOI 10.1146/annurev-immunol-080219023629.

Strokappe N.M., Hock M., Rutten L., Mccoy L.E., Back J.W., Caillat C., Haffke M., Weiss R.A., Weissenhorn W., Verrips T. Super potent bispecific llama VHH antibodies neutralize HIV via a combination of gp41 and gp120 epitopes. Antibodies (Basel). 2019;8(2). DOI 10.3390/antib8020038.

Strokappe N., Szynol A., Aasa-Chapman M., Gorlani A., Forsman Quigley A., Hulsik D.L., Chen L., Weiss R., De Haard H., Verrips T. Llama antibody fragments recognizing various epitopes of the CD4bs neutralize a broad range of HIV-1 subtypes A, B and C. PLOS One. 2012;7(3):e33298. DOI 10.1371/journal.pone.0033298.

Tikunova N.V., Morozova V.V. Phage display on the base of filamentous bacteriophages: application for recombinant antibodies selection. Acta Naturae. 2009;1(3):20-28.

Walker L.M., Phogat S.K., Chan-Hui P.Y., Wagner D., Phung P., Goss J.L., Wrin T., Simek M.D., Fling S., Mitcham J.L., Lehrman J.K., Priddy F.H., Olsen O.A., Frey S.M., Hammond P.W., Investigators P.G.P., Kaminsky S., Zamb T., Moyle M., Koff W.C., Poignard P., Burton D.R. Broad and potent neutralizing antibodies from an African donor reveal a new HIV-1 vaccine target. Science. 2009;326(5950):285-289. DOI 10.1126/science.1178746.

Walker L.M., Simek M.D., Priddy F., Gach J.S., Wagner D., Zwick M.B., Phogat S.K., Poignard P., Burton D.R. A limited number of antibody specificities mediate broad and potent serum neutralization in selected HIV-1 infected individuals. PLoS Pathog. 2010;6(8):e1001028. DOI 10.1371/journal.ppat.1001028.

Weiss R.A., Verrips C.T. Nanobodies that neutralize HIV. Vaccines (Basel). 2019;7(3). DOI 10.3390/vaccines7030077.

Winter G., Griffiths A.D., Hawkins R.E., Hoogenboom H.R. Making antibodies by phage display technology. Annu. Rev. Immunol. 1994;12(433-455). DOI 10.1146/annurev.iy.12.040194.002245.

Wu X., Yang Z.Y., Li Y., Hogerkorp C.M., Schief W.R., Seaman M.S., Zhou T., Schmidt S.D., Wu L., Xu L., Longo N.S., Mckee K., O'dell S., Louder M.K., Wycuff D.L., Feng Y., Nason M., DoriaRose N., Connors M., Kwong P.D., Roederer M., Wyatt R.T., Nabel G.J., Mascola J.R. Rational design of envelope identifies broadly neutralizing human monoclonal antibodies to HIV-1. Science. 2010; 329(5993):856-861. DOI 10.1126/science.1187659.

Zhang M.Y., Choudhry V., Sidorov I.A., Tenev V., Vu B.K., Choudhary A., Lu H., Stiegler G.M., Katinger H.W., Jiang S., Broder C.C., Dimitrov D.S. Selection of a novel gp41-specific HIV-1 neutralizing human antibody by competitive antigen panning. J. Immunol. Methods. 2006;317(1-2):21-30. DOI 10.1016/j.jim.2006.09.016.

Zhang M.Y., Shu Y., Phogat S., Xiao X., Cham F., Bouma P., Choudhary A., Feng Y.R., Sanz I., Rybak S., Broder C.C., Quinnan G.V., Evans T., Dimitrov D.S. Broadly cross-reactive HIV neutralizing human monoclonal antibody Fab selected by sequential antigen panning of a phage display library. J. Immunol. Methods. 2003; 283(1-2):17-25. http://dx.doi.org/10.1016/j.jim.2003.07.003. 
Zhang M.Y., Shu Y., Rudolph D., Prabakaran P., Labrijn A.F., Zwick M.B., Lal R.B., Dimitrov D.S. Improved breadth and potency of an HIV-1-neutralizing human single-chain antibody by random mutagenesis and sequential antigen panning. J. Mol. Biol. 2004a; 335(1):209-219. DOI 10.1016/j.jmb.2003.09.055.

Zhang M.Y., Xiao X., Sidorov I.A., Choudhry V., Cham F., Zhang P.F., Bouma P., Zwick M., Choudhary A., Montefiori D.C., Broder C.C., Burton D.R., Quinnan G.V., Jr., Dimitrov D.S. Identification and characterization of a new cross-reactive human immunodeficiency virus type 1-neutralizing human monoclonal antibody. J. Virol. 2004b;78(17):9233-9242. DOI 10.1128/JVI.78.17.92339242.2004.

Zhang M.Y., Yuan T., Li J., Rosa Borges A., Watkins J.D., Guenaga J., Yang Z., Wang Y., Wilson R., Li Y., Polonis V.R., Pincus S.H., Ru- precht R.M., Dimitrov D.S. Identification and characterization of a broadly cross-reactive HIV-1 human monoclonal antibody that binds to both gp120 and gp41. PLoS One. 2012;7(9):e44241. DOI 10.1371/journal.pone.0044241.

Zhao A., Tohidkia M.R., Siegel D.L., Coukos G., Omidi Y. Phage antibody display libraries: a powerful antibody discovery platform for immunotherapy. Crit. Rev. Biotechnol. 2016;36(2):276-289. DOI 10.3109/07388551.2014.958978.

Zwick M.B., Bonnycastle L.L., Menendez A., Irving M.B., Barbas C.F., 3rd, Parren P.W., Burton D.R., Scott J.K. Identification and characterization of a peptide that specifically binds the human broadly neutralizing anti-human immunodeficiency virus type 1 antibody b12. J. Virol. 2001;75(14):6692-6699. DOI 10.1128/JVI.75.14.6692-6699. 2001.

\section{ORCID ID}

A.N. Chikaev orcid.org/0000-0001-5423-3457

A.P. Rudometov orcid.org/0000-0003-2808-4309

lu.A. Merkuleva orcid.org/0000-0002-6974-0686

L.I. Karpenko orcid.org/0000-0003-4365-8809

Acknowledgements. The reported study was funded by the Russian Foundation for Basic Research (project No. 20-04-00879).

Conflict of interest. The authors declare no conflict of interest.

Received January 12, 2021. Revised March 14, 2021. Accepted March 22, 2021. 